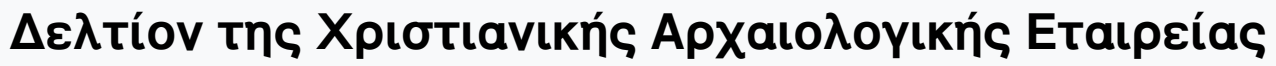

Tó 12 (1986)

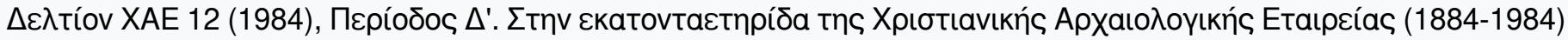

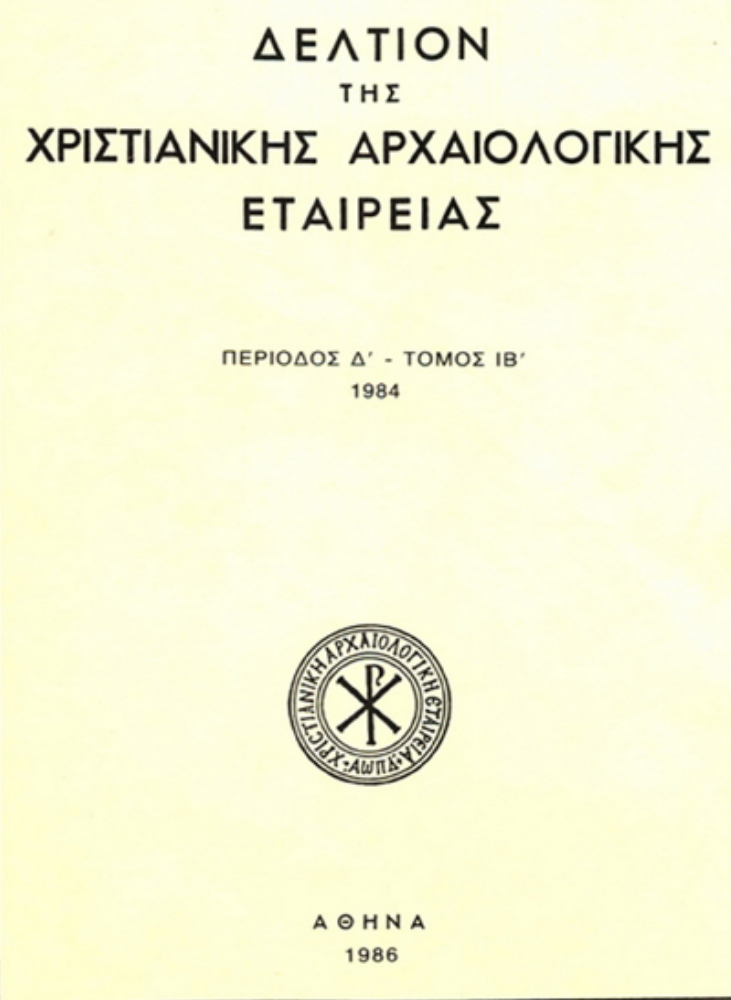

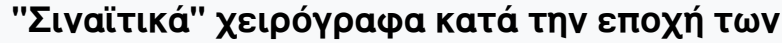
Apáßwv

George GALAVARIS

doi: $10.12681 /$ dchae. 948

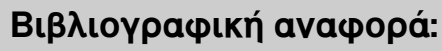

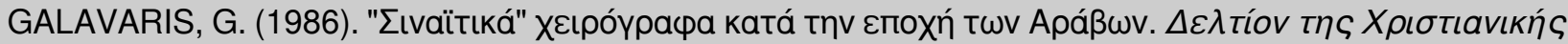

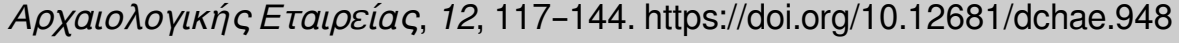




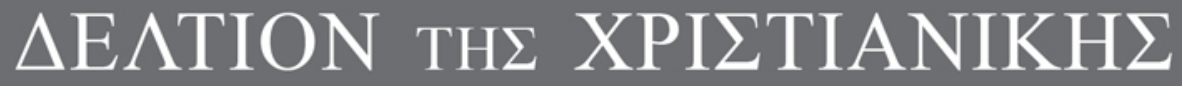 APXAIO $\Lambda$ OГIKH $\Sigma$ ETAIPEIA $\Sigma$}

"Sinaitic" Manuscripts in the Time of the Arabs

George GALAVARIS

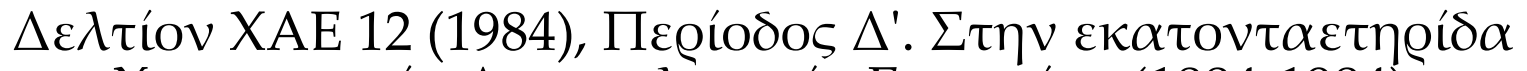

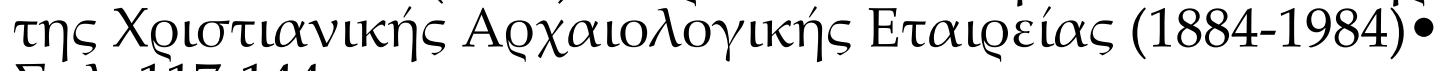
$\sum \varepsilon \lambda .117-144$

A@HNA 1986 


\section{"SINAITIC" MANUSCRIPTS IN THE TIME OF THE ARABS}

The deep debt which like all students of Byzantium I owe to the Christian Archaeological Society for its manifold, most important contributions to scholarship during an entire century cannot be sufficiently expressed in my present offering. It is to be hoped, however, that it constitutes a meaningful addition to the work of all those who have brought us nearer to Sinai "the God-trodden Mountain" that towers up as a great landmark in the activities of members and friends of the Society. Their names form a long list but I would like at least to mention here the names of Konstantinos Amantos, George and Maria Soteriou, Manolis Chatzidakis and Kurt Weitzmann ${ }^{1}$.

Weitzmann singled out problems pertaining to manuscripts now in Sinai in his survey of the monastic library in general, a brief but seminal work, and in the publication of a codex of John Climacus in particular in which he stressed the importance of Islamic and Coptic influences for the study of Sinaitic manuscripts ${ }^{2}$.

My intention is to advance these problems further in this paper and to sketch out a clear although preliminary image of Sinaitic activities in the area of illuminated manuscripts which begins to be developed after the detailed work done on each codex in the forthcoming catalogue of the Sinai manuscripts prepared by Weitzmann and the present writer. I cannot deal here with all codices certainly or possibly produced at Sinai. A choice of representative examples from the eighth to the fourteenth century has been made which is indicative of the tendencies that manuscript illumination has taken in this monastic centre. There are some exceptions which are too complicated and

1. For recent, general bibliographies on Sinai mostly historically oriented and not complete,

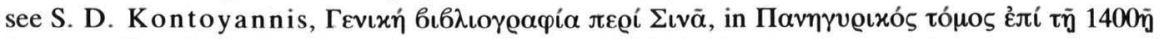

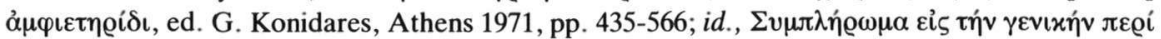

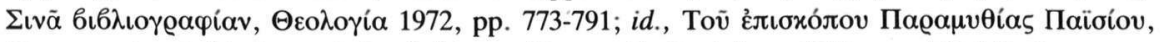

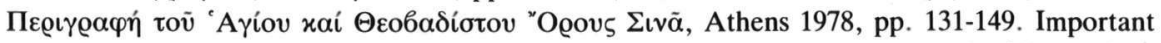
material and bibliographies have also been presented by D. Papastratou, ed., 'O Eıvaitns

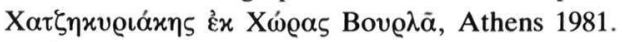

2. K. Weitzmann, Illustrated Manuscripts at St. Catherine's Monastery on Mount Sinai, Collegeville, Minnesota 1973; id., Islamische und Koptische Einflüsse in einer Sinai-Handschrift des Johannes Klimakus, in Aus der Welt der Islamischen Kunst, Festschrift für Ernst Kühnel, Berlin 1969, pp. 297-316. 
problematic to be dealt with here ${ }^{3}$. The first date marks the earliest extant ornamented manuscripts. The second chronological border does not signify the end of copying and illuminating activities in the monastery but rather the conclusion of a long chapter or chapters (it all depends on how one categorizes the material) in the history of book production. All codices presented here are destined for liturgical use: psalters, lectionaries, sticheraria, kondakaria, akolouthiai. I have included, however, a codex with the text of John Climacus, a justified exception since its reading forms an integral, necessary part of monastic life. Most of these codices are neither dated nor placed at Sinai by any form of written evidence.

It is not necessary to cite here the criteria -they are well known- which one considers in such instances in order to reach a possible solution of the problem. But I would like to stress that apart from these factors, one must try to understand the approach of a particular artist to the decoration of a manuscript, i.e. the over-all effect which a codex produces beyond the particulars of a possible copying of a certain motif or form. The details of the argument will be found in the forthcoming catalogue. Here I shall first present the distinct character of the manuscripts which in some instances is known but in this paper new, fundamental elements are added and the entire material is seen in a different dimension. At the end, I shall try to interpret the evidence.

\section{II}

Among the earliest codices extant in the library of the monastery there are a number of psalters which can be dated to the eighth and ninth century ${ }^{4}$. Their common features are: the thickness and hardness of the parchment; the majuscule script of the sloping and upright types written in black ink with a very thick pen and the ornament (Fig. 1). The titles and in some instances the texts are written in Greek and Arabic. Among the listed manuscripts at Sinai, there are actually three such bilingual psalters, properly speaking, codd. 34, $35,36^{5}$. Other examples have only an occasional Arabic text contemporary with the Greek text. No one of these codices contains figurative illustrations but only ornament the repertory of which is limited to a simple interlace or

3. One of these possible exceptions has been studied in another context by D. Mouriki in her excellent dissertation, unpublished, The Octateuch Miniatures of the Byzantine Manuscripts of Cosmas Indicopleustes, Princeton 1970.

4. Weitzmann, Sinai Mss, pp. 9, 10.

5. V. E. Gardthausen, Catalogus codicum graecorum Sinaiticorum, Oxford 1886, pp. 2, 9, 10, pl. I, no. 3; Weitzmann, Islamische Einflüsse, p. 314, fig. 17; id., Sinai Mss, fig. 3. 
interlaced crosses outlined and tinted as seen, for example, in cod. 32 (Fig. 1) ${ }^{6}$. The colour scheme which persists now and later comprises red in an orange or terracotta hue, deep olive green, pale yellow and light brown, colours which have an early history in book illumination. As far as we know, depending on our present evidence, they appear in early codices which have been associated with Egypt although in later centuries, after the ninth century, they are found in other provincial areas as well for which earlier evidence is lacking ${ }^{7}$.

Among these psalters, cod. 32, cited above, contains evidence indicating that it was produced in Sinai. On fol. $374 v$, at the conclusion of the 150th psalm, one reads the following written in the same

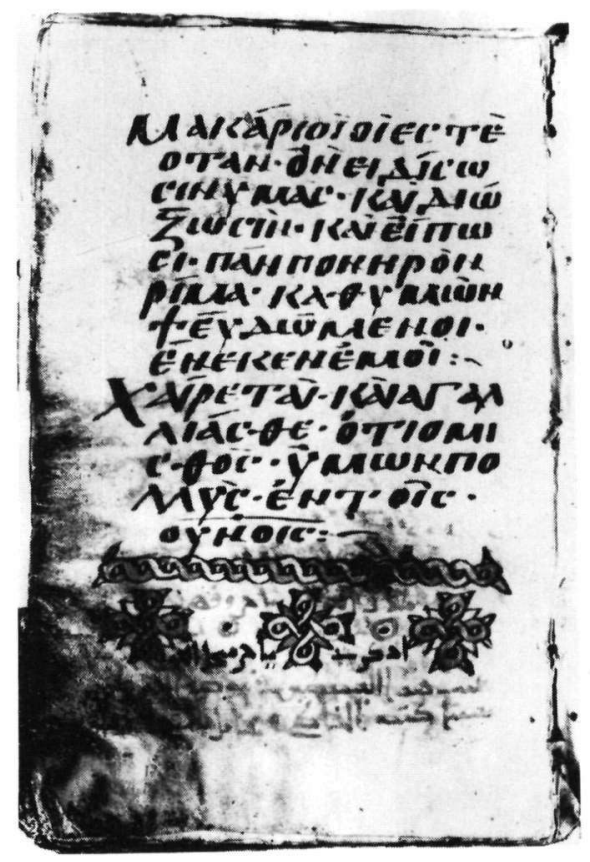

Fig. 1. Psalter. Cod. 32. Fol. 408v. type of script in red ink except for the number of verses which is in black: 'EXOYCIN OÝN O[ı]: $\overline{P N}: \Psi A \Lambda$ -

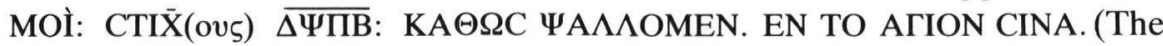
150 psalms have, then, 4782 verses as we chant them in Holy Sinai).

Consequently, it would be reasonable to assume that the relatives of this psalter with which it shares similar codicological and artistic features were made in Sinai or at least in a nearby centre with which Sinai had close connections. In fact the evidence of cod. 32 and my drawn assumption are

6. Gardthausen, op. cit., p. 9; V. N. Benešević, Catałogus codicum manuscriptorum graecorum, qui in monasterio Sanctae Catherinae in monte Sina asservantur, I and III, 1, St. Petersburg 1911, 1914 (in Russian), repr. Hildesheim 1965, 1, p. 25; the most recent list with the re-numbering of the manuscripts by M. Ka mil, Catalogue of All Manuscripts in the Monastery of St. Catherine on Mt. Sinai, Wiesbaden 1970, is useless. Similar ornament appears in some of the newly discovered codices.

7. Cf. K. Weitzmann, ed., Age of Spirituality, Catalogue of the Exhibition at the Metropolitan Museum of Art, N. York 1979, no. 44a, p. 494. For some later examples assigned to various provinces see cod. Oxford Laud. gr. 293, I. Hutter, Corpus der byzantinischen MiniaturHandschriften (Österreichische Akademie der Wissenschaften) 1: Oxford, Bodleian Library, 1, Stuttgard 1978, no. 15, fig. 81; Princeton gospels, Univ. Lib. cod. Garret 1, G. Vikan, ed., Illuminated Greek Manuscripts from American Collections, Exhibition in Honour of K. Weitzmann, Princeton 1973, no. 2; cf. K. Weitzmann, Die byzantinische Buchmalerei des 9. und 10. Jahrhunderts, Berlin 1935, pp. 72 ff. 
strengthened if one considers the use of these codices.

These bilingual psalters presuppose bilingual readers and must have been produced to meet the demands of Arab-Christians or Arabic speaking Egypto-Palestinians in a centre where this bilingualism or multilingualism was present. And although the monastery of the Holy Sepulchre in Jerusalem had attracted Arabic speaking monks, that centre of production most likely was Sinai where the multilingual tradition was strong. Already before the arrival of the Arabs, we know that Sinai had recruits from various regions. PseudoAnthony of Piacenza who visited Sinai in 570 reports that there were three "abbates" who spoke Latin, Greek, Syriac, Egyptian or Coptic and even the language of the ancient Thracians ${ }^{8}$. With the coming of the Arabs, Arabic speaking monks constituted a predominant element in the life of the monastery. A simple but eloquent echo of this has survived in the Proskynetaria of Sinai ${ }^{9}$. The existence of about twenty-five early bilingual, Greco-Arabic codices among the recent manuscript-discoveries at Sinai, leaves no doubt about the strong presence of Arab-Christians there and the production of such manuscripts for their own use.

This type of production continues in a number of ninth century lectionaries written on hard parchment and in the same form of script -the effect of this hieratic script is astonishing- as the early psalters. Devoid of figural illustrations these lectionaries repeat the ornament found in the psalters, i.e. the interlace and occasionally their initials which are large in size take the form of a stylized fish as, for example, in cod. 211. The special consideration which all these codices deserve cannot be attempted here. The question whether all or some of them were produced in Sinai itself must be left open. But even if the production of some of these lectionaries did take place in a nearby centre with which Sinai had close connections, Jerusalem for example, there is good evidence to show that they were made for Sinai. At least this is the case with the cod. 210 and its newly discovered not simply fragments but missing "gatherings" МГ12. The long colophon of cod. 210, fol. 63v, which

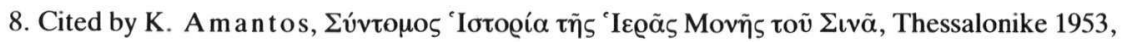
p. 18.

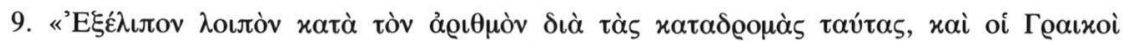

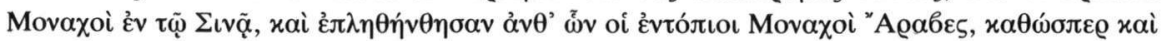

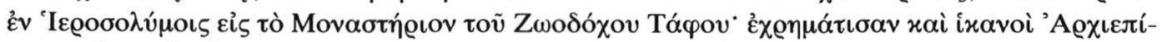

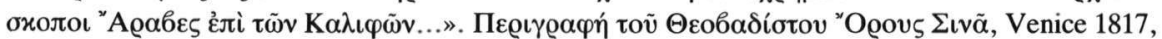
reprinted by the Holy Monastery of Sinai, Athens 1978. 
is not even mentioned in the most recent publication of the codex, shows that the lectionary was intended for Sinai ${ }^{10}$.

However, in the tenth century there appear two manusripts sophisticated in their imaginative type and use of script and their wise approach to the decoration. They are different from one another in terms of script, ornament and system of ornamentation. And yet apart from the hard parchment and colour scheme which they have in common, they reveal similar artistic tendencies: almost exclusively uniconic elements, emphasis on ornament and strong Islamic influences.

The first codex containing the text of John Climacus has been fully discussed by Weitzmann who

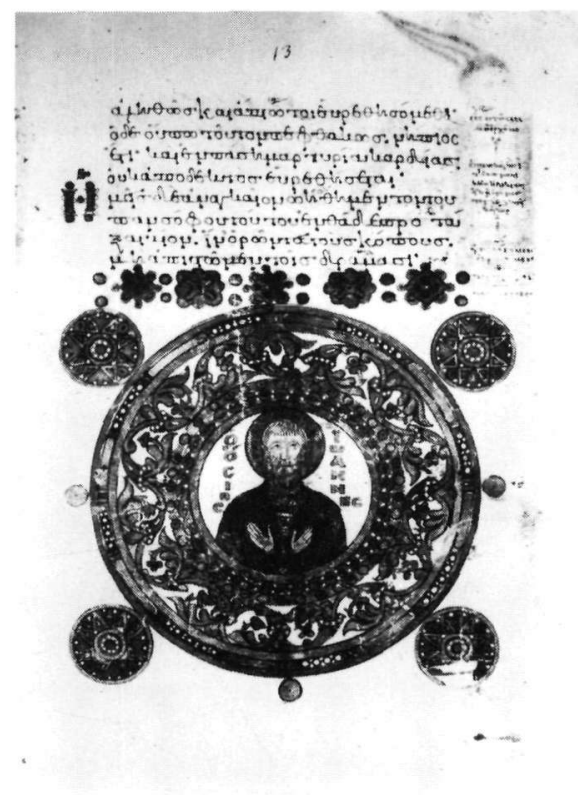

Fig. 2. John Climacus. Cod. 417 (fol. 13r). dates it to the mid-tenth century. It contains only one figurative illustration, the author's portrait in a medallion form (Fig. 2). The rinceau ornament in the frame of this bust has been related by Weitzmann to the mosaics of the Dome of the Rock in Jerusalem and other monuments of Early Moslem art; while the abstract patterns in the medallions set on the four corners betray Coptic influences ${ }^{11}$. The ornament throughout the manuscript in the form of imaginative headbands is of high quality. Nevertheless it is removed from Constantinopolitan art both in terms of form and colours. The forms are thick or heavy and the colours are deep green, blue and red (Figs. 3-4). Furthermore the roundels attached at the beginning of some ornamental bands, fol. 235r, for instance, are typical for the decoration of the koran serving to mark the beginning of a

10. For a reproduction of an initial in the form of a fish from cod. 211 see Weitzmann, Sinai Mss, p. 9, fig. 2, with the earlier bibliography. The most recent publication of only one leaf MГ12 and its parent manuscript cod. 210 is by D. Harflinger, D. R. Reinsch and J. A. K. Sonderkamp, Specimina Sinaitica, Die datierten Handschriften des Katharinen-Klosters auf dem Berge Sinai 9. bis 12. Jahr., Berlin 1983, no. 1, pls. 1-4. Actually the newly discovered folios that belong to cod. 210 comprise five gatherings, altogether 18 folios and 5 fragments.

11. Id., Islamische Einflüsse, pp. $40 \mathrm{ff}$. 
sura (Fig. 4). The beautiful script which combines majuscule and minuscule scripts of different types is not easy to classify. Hunger would have included the minuscule script in his examples of the Kirchenlehrerstil ${ }^{12}$. Whatever its accepted classification may be, it impresses us by its hieratic quality and its monumentality. In the palaeography reflections of Constantinopolitan scriptoria are to be seen but also influences coming from the Coptic and Islamic worlds ${ }^{13}$. Considering all these elements and our observations on the earliest group of manuscripts, it seems highly unlikely that this codex is not a Sinaitic product.

The second manuscript of this period is a lectionary, cod. 213, which has not been fully published as yet. According to its colophon, fols. 340v and 1v, it was written in the year 967 by a certain presbyter Eustatheios ${ }^{14}$. A Greek note which has escaped the attention of the art historians who have dealt with the codex, written by a different hand in a later script following the colophon on fol. 240v, states that "the present holy gospel of the most Holy Theotokos of the Holy Mount Horeb was dedicated by the hand of Macarios the most holy archbishop of the Holy Mount Sinai"15. Another note in Arabic along the right margin of fol. $3 r$, which according to Arabists seems to be a little later than the gospel-text, associates the codex to Mount Horeb (Fig. 5) ${ }^{16}$. As a result of these notes the lectionary has become known in the monastery as the Horeb gospels.

Amantos in his researches on bishops of Sinai was attracted by the contents of the Greek note ${ }^{17}$. Although he could not decide on its date or that of the named bishop Macarios, he pointed out the importance of the note ${ }^{18}$. It makes no mention of St. Catherine. Instead it refers to the monastery as that of the Theotokos of Mt. Horeb to whom, according to Procopios, it was dedicated by Justinian ${ }^{19}$. Recently this note has been given a twelfth-thirteenth century date by palaeographers ${ }^{20}$ by which time the monastery was known as that of St.

12. H. Hunger, Minuskel und Auszeichnungsschriften im 10.-12. Jahrhundert, Colloques Inter. C.N.R.S., no. 559, La Paléographie grecque et byzantine, Paris 1977, p. 204, figs. 7, 8.

13. Weitzmann, Islamische Einflüsse, pp. $310 \mathrm{ff}$.

14. I. Spatharakis, Corpus of Dated Greek Manuscripts to the Year 1453, Leiden 1981, no. 18, figs. 42, 43 with earlier bibliography; and Harflinger et al., op. cit., no. 2, pls. 5-9.

15. For the Greek text, see Harflinger et al., op. cit., pl. 9 (b).

16. For an English translation, see Weitzmann, Sinai Mss, p. 10, n. 19.

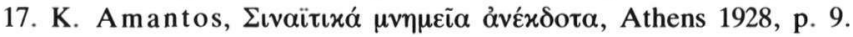

18. Concerning the list of bishops at Sinai new light is thrown by the new Greek manuscriptfinds.

19. Cf. A. Guillou, Le monastère de la Theotokos au Sinai, Mélanges d'archéologie et d'histoire 67 (1955), pp. 217-258.

20. Harflinger et al., op. cit., no. 2, p. 15. 
Catherine. It is logic, therefore, to conclude that the note does not refer to contemporary events but to an earlier period before the arrival of the cult of St. Catherine at Sinai which can be attested since the beginning of the eleventh century. Whether the unknown scribe records information that may have existed in the monastic library or transmits an oral tradition we cannot know. The fact is that he takes us back to a time near the date of the completion of the

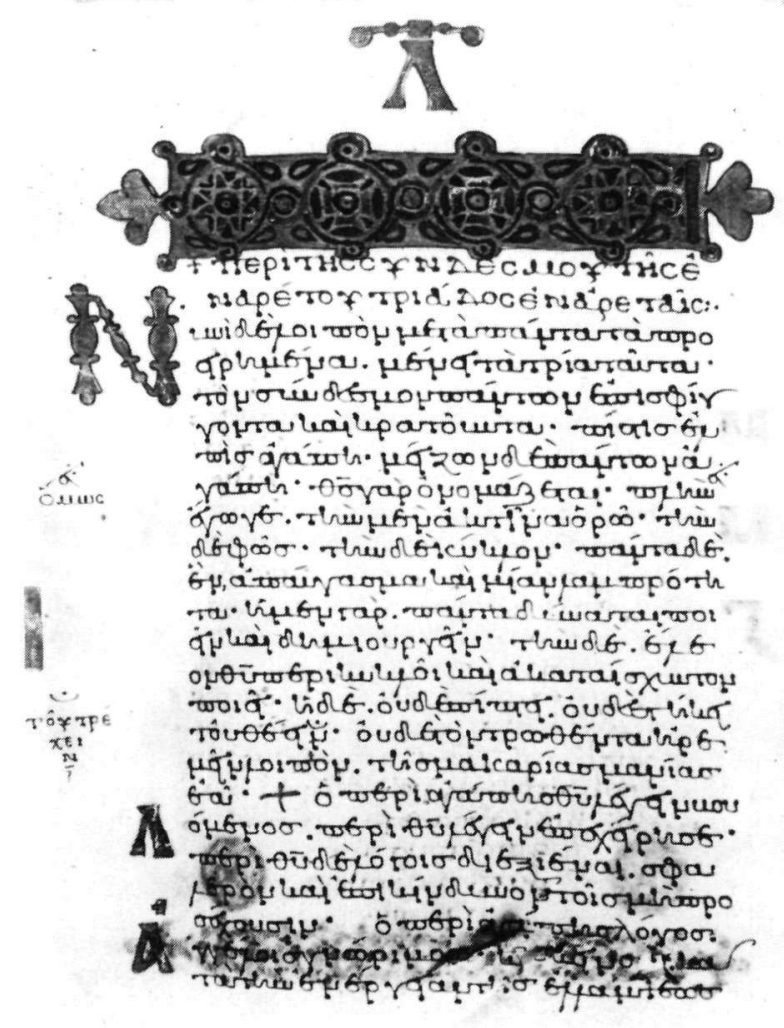

Fig. 3. John Climacus (fol. 229v).

codex. This is of special significance; for it means that the manuscript may have been connected with Sinai since the very beginning, although no proof is provided that it was necessarily produced in the monastery.

The Horeb gospel combining two types of majuscule script, the sloping and the upright one, which relate to the script found in the early bilingual codices, has titles outlined and coloured in terracotta or light red, strong ultramarine, pale yellow and light and dark olive green and it is extraordinary for its wealth of ornament rendered in colours similar to those in the titles. It is important to re-iterate that this colour scheme persists in Sinaitic productions and that it also appears in a group of "orientalizing" icons, all of them unpublished, which are in Sinai. Apart from several headpieces, there are more than 150

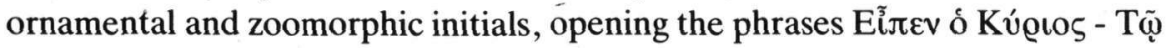

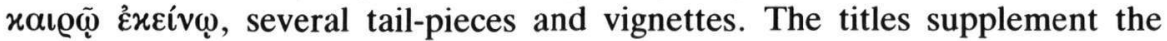
ornament; they are often juxtaposed to the text filling a complete column (Fig. 


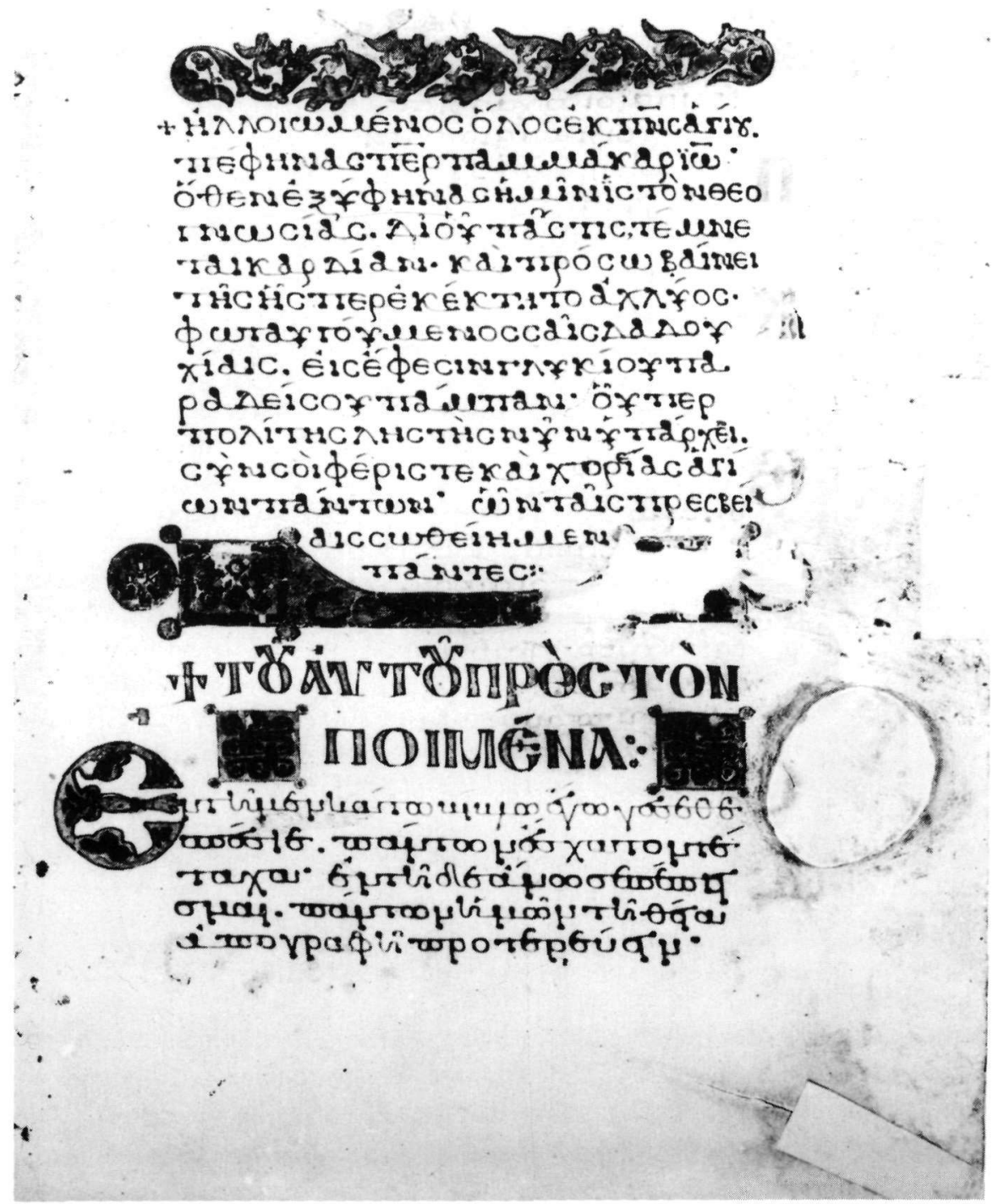

Fig. 4. John Climacus (fol. 235r).

9). The ornament is so applied as to distinguish or emphasize sections of the book and lections of the text. Turning the folios amidst this wealth of ornamentation we discover, hidden as it were, a medallion-bust of Christ (Fig. 10). It is the only figurative, iconic illustration properly speaking in the entire codex, placed at the beginning of the Passion pericopes.

The ornament as such shows an exaggerated combination of motifs in the same band or the same initial. For example, on fol. $196 \mathrm{v}$ we see palmettes, 
interlace, a dragon-like head, a human head, all combined (Fig. 10). The application of various patterns creates the feeling of "horror vacui". Most initials are characterized by a forearm, looking like a piece of jewellery and a blessing hand. The motif of the blessing hand is known in Byzantine illuminated codices, particularly in lectionaries written in majuscule script where it marks the beginning of pericopes ${ }^{21}$. The "Sinai" hands, however, are very distinct for they are combined whether on a band on an initial, fols. $312 \mathrm{v}$, $196 \mathrm{v}$, for instance, with an animal form which can have an explicit character snake-like or dragon-like or be abstract (Figs. 5, 8, 10, 11).

As we look at these imaginary compositions, we wonder whether this snake resembling a viper with a wide open, staring eye is to devour the hand -Manor it is to be crushed by the divine power of this hand. Do we have, in other words, symbolic representations of the fight of good against evil ${ }^{22}$ ? It is not my intent to enter into this question here. What is significant in the context of the discussion is that the zoomorphic element is the most distinct characteristic of the codex.

The preferred animal is the griffin found in initials and vignettes. It is alive and threatening, alone or combined with hands or with the human figure as on fol. $19 \mathrm{v}$ in which we see a composition reminding us of representations of the Ascension of Alexander on the griffin-chariot (Figs. 6-8, 11) ${ }^{23}$. As a subject the griffin is an old one in the repertory of art. It is not uncommon in Byzantine manuscripts produced in various areas and as a motif it does not help solve problems of provenance of a codex. It is the rendering of a griffin that is significant. In our case it is set apart by certain particular features. The thigh is adorned with an almond; the wings are stripped and jewel-studded; the neck has a band also jewel-studded; the tail terminates into a leaf. This imaginary animal becomes so orientalized that it looks like one of the Sassanian products which were spread throughout the Near East including Egypt as a comparison, for instance, with a bronze griffin probably made in Egypt in the eleventh century can show, and which had an impact on Byzantine ornamentation $^{24}$.

21. See, for example, Athens cod. 60, fol. 79r, A. Marava-Chatzinicolaou, Ch. Toufexi-Paschou, Catalogue of the Illuminated Byzantine Manuscripts of the National Library of Greece (Academy of Athens), Athens 1978, no. 3, fig. 19.

22. Cf. the excellent study of L. Bouras, Dragon Representations on Byzantine Phialae and Their Conduits, Gesta 16 (1977), pp. 65-68.

23. Weitzmann, Buchmalerei, p. 74; cf. C. Settis-Frugoni, Historia Alexandri elevati per griphos ad aerem (Istituto storico italiano per il Medio Evo, Studi storici, fasc. 80-82), Rome 1972.

24. See D. Talbot Rice, Islamic Art, London 1965, p. 94, fig. 93. Questions of Sassanian and Islamic influences on Byzantine ornamentation have repeatedly attracted scholarly attention in

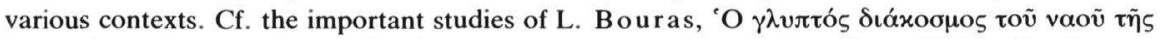

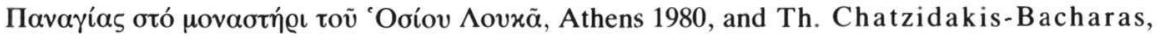
Les peintures murales de Hosios Loukas, Athens 1982. 


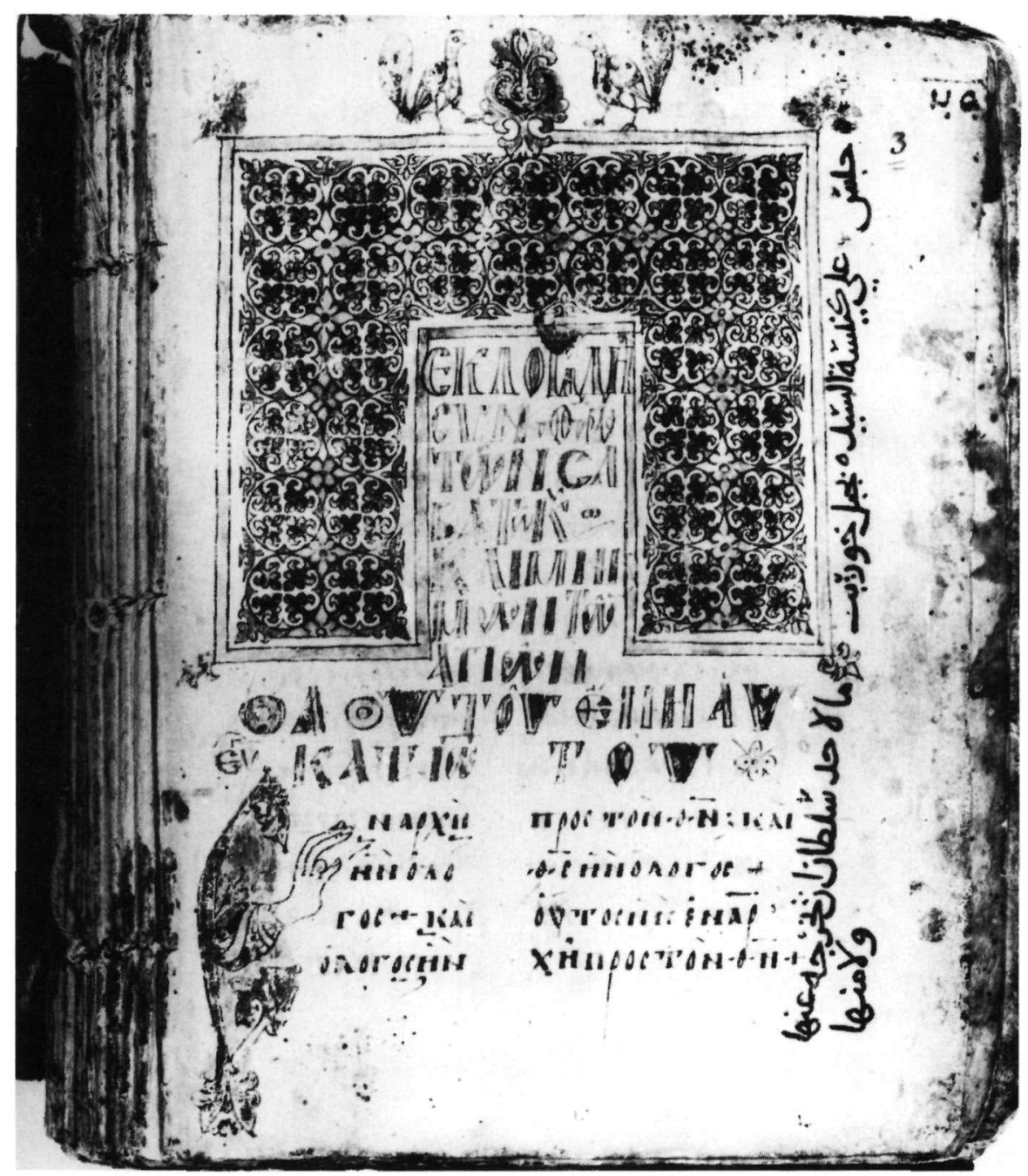

Fig. 5. Horeb Lectionary. Cod. 213. Fol. 3r.

Even the Holy Ghost is subjected to this stream of orientalization (Fig. 8). One would not realize that this bird which really cannot fly because it is affixed on the top of the page like a jewel represents the Holy Ghost. We learn this by reading the pericope below and which is Matt. 18:10-20, the lesson for the feast of the Holy Ghost. It is unnecessary to mention here that these representations, the Holy Ghost at the relevant feast and the bust of Christ at the Passion lections and even the different sizes in the ornament - all these are points of reference to the text; they are "devices" which help the reader find a particular reading. 
Islamic influences must be sought also for the ornament on the headpiece introducing the Easter Sunday lection (Fig. 5). It is not unlike stone carvings such as those on the facade of the mosque Al-Hakim in Cairo (990-1003) which probably follows earlier Islamic decorations or the ornament on the wooden doors from the mosque Al-Azhar also in Cairo from the year $1010^{25}$.

Considering the over-all character of the codex, the script which is typical for the manuscripts produced in the Sinai area, the ornamental motifs, their orientalized style, their parallels and the Islamic influences, the attribution of this particular codex to S. Italy, notwithstanding the relations of Sinai with that area, is not tenable ${ }^{26}$. On the contrary, Weitzmann's view for an Eastern origin of the codex gains support ${ }^{27}$. The Horeb lectionary presupposes a territory where the diverse cultural streams, indicated already, met, an area in which the restrain of the "iconic" representation was necessary, that is an Islamic milieu. Its long association with Sinai stressed above, makes the latter or a centre nearby the most likely place of its production.

If one considers what went on in Constantinople at the time when these two manuscripts were produced, the period of the Macedonian Renaissance, and think of the richness of various codices in terms of pictorial cycles and the abundant use of gold and brilliant colours ${ }^{28}$, we can refer, for example, to the extraordinary miniatures in the lectionary cod. 204 now in the monastery (Fig. $12)^{29}$, the uniconic element and the differences in approach to the decoration presented by the two tenth-century codices dealt with here, come into sharp focus. Despite the differences both these books represent well trained scribes, competent and imaginative illustrators of whom the one responsible for the Horeb gospel was the most exuberant.

The reference to Constantinopolitan products and their presence in the library today raise a number of questions: is the uniconic element due only to the Islamic surroundings in which Sinai has existed or have the monks been cut

25. Talbot Rice, op. cit., p. 88 , figs. 86,87 .

26. This hypothetical attribution was proposed by A. Grabar, Les manuscrits grecs enluminés de provenance italienne (IXe-XIe siècles), Paris 1972, p. 73. The entire question of assigning Greek manuscripts to S. Italy needs reconsideration: repertory as such, colours and size of initials cannot be considered as indications of an Italian origin for they do occur in products of various geographic areas. A study of linguistic idioms, among other criteria, may yield more significant results.

27. Weitzmann, Sinai Mss, pp. 10, 11.

28. Id., Geistige Grundlagen und Wesen der Makedonischen Renaissance, Cologne and Opladen 1963, reprinted in an English translation in id., Studies in Classical and Byzantine Manuscript Illumination, H. L. Kessler, ed., Chicago, London 1971, no. 8.

29. Ibid., pp. 164-166, 222; figs. 134-144, 209 with earlier bibliography. 

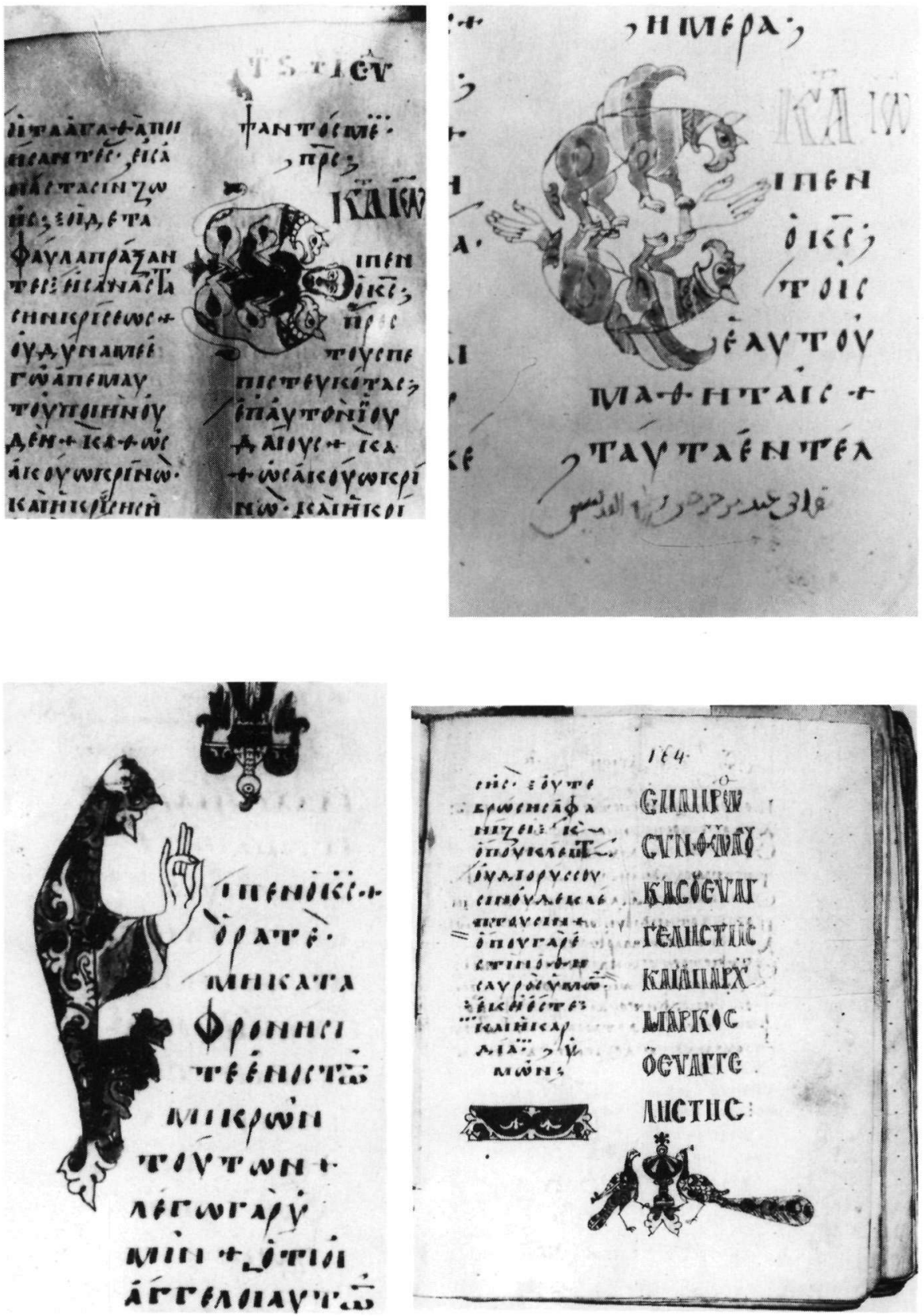

Figs. 6-9. Horeb Lectionary. Cod. 213 (6. Fol. 19v; 7. Fol. 28v; 8. Fol. 75v; 9. Fol. 164r). 

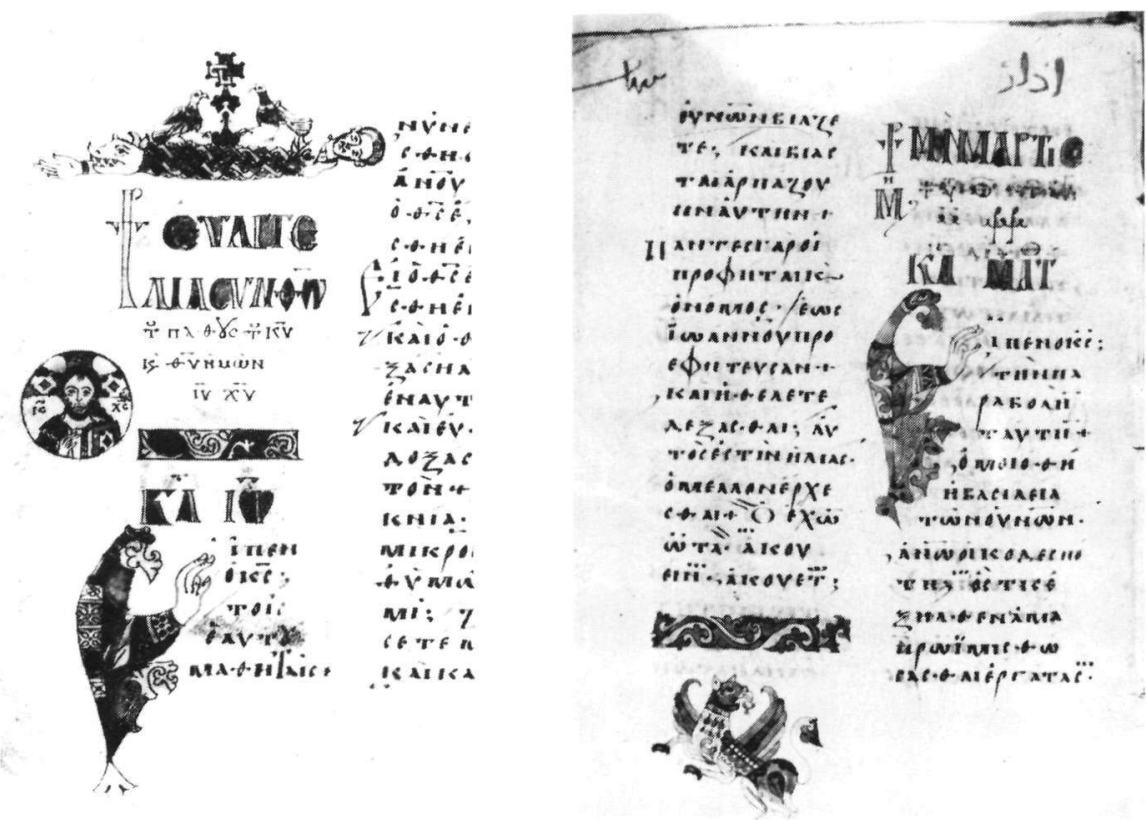

Figs. 10-11. Horeb Lectionary. Cod. 213 (10. Fol. 196v; 11. Fol. 321v).

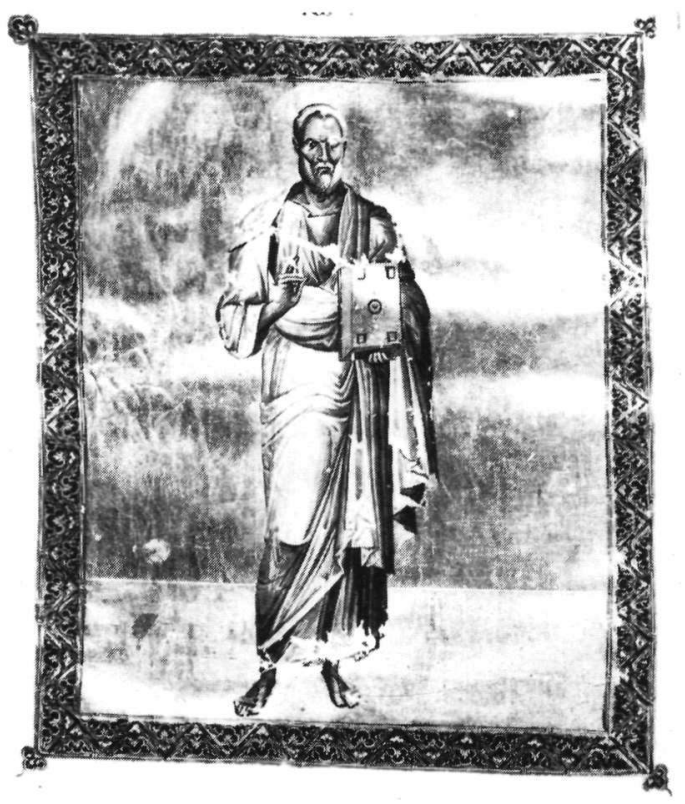

Fig. 12. John the Evangclist. Cod. 204. Fol. 8v (p. 14). 
off from Constantinopolitan products? What was the role played by works of the Capital if they were in the monastery at the time? We shall return to these questions later.

In what follows after the end of the tenth century we see a continuity of the tradition represented by all these manuscripts and attempts made by the artists in order to revitalize it. Among the twelfth-century codices there is a lectionary, cod. 207, which displays a headband of particular significance (Fig. $15)^{30}$. Although at first it may look like a Cufic ornament, in fact it is an Arabic inscription which is not a translation of the Greek title or text as the case is with the Greco-Arabic psalters. It reads: "There is no God but God and Muhammad is his prophet" ${ }^{31}$. Obviously this is the sentence which appears in the opening part of every koran. Rendered in red, as all the headbands in the codex, this "inscription" is contemporary with the Greek text. In fact it takes the place of an ornamental band marking the pericope from Mark (2:23-3:2) for the first Saturday of Lent and the feast day of Theodore the Megalomartyr. The calligrapher must have been an Arabic speaking Christian who had no difficulty in copying a koran-sentence. Whether he was attracted by the decorative possibilities of the script or simply he thought it was not inappropriate for such a sentence to mark the gospel of Christ as well - this is immaterial. The important fact is that he was familiar with the Mohammedan sacred book. The erection of a mosque in Sinai itself before the year 1100 would have given to the Arab-Christian "scribes" a special chance to see, possibly to admire the koran and to become so familiar with it as to use it as a source for headbands in gospels ${ }^{32}$.

In the headpiece of the same codex, fol. Ir (Fig. 13), we recognize in the hesitance of introducing the portrait of John the Evangelist and in the repertory (griffins and other animals), style and colour of the ornament, corrupt reflections of the Horeb gospel and of another eleventh-twelfth century lectionary, cod. 214, which has been produced possibly at Sinai (Fig. $16)^{33}$.

30. The codex is unpublished and it has not been noted by Gardthausen or Benešević; but it is listed by Kamil, op. cit., p. 70, no. 232.

31. For the reading of the Arabic text I am indebted to Mrs. Salwa Ferahian of the Institute of Islamic Studies, McGill University.

32. The exact date of the construction of the mosque is not known. A dedicatory Cufic inscription on the ambo (minbar) of the mosque establishes the date 1106 for the ambo; hence the

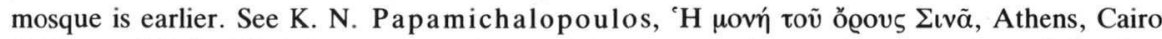
1932, pp. 238 f., 241 f. Important, written evidence supporting my interpretations of the data presented in this paper and concerning the strong presence, copying and translating activities of Arab-Christians at Sinai is provided by the newly discovered Arab texts.

33. Unpublished; Gardthausen,op. cit., p. 43; Benešević, op. cit., 1, p. 643; Kamil, op. cit., p. 70, no. 239. 
Related to these, although the forms are still cruder, is another lectionary from the late twelfth-century, cod. 237, which in spite of its artistic poverty show how stretched the strings of an old tradition have become $\mathrm{e}^{34}$. Its large headpiece introducing the Easter Sunday lection presents familiar motifs (Fig. 17): griffins, lions resembling griffins and birds -all orientalized, in medallions with palmettes between them in a rough flower petal style; strange birds on the extended lower lines of the headpiece; the initial $\mathrm{E}$ with a blessing hand and the lion-griffin below on the margin. The placing of this last motif on the margin should be particularly pointed out -for it is almost a point of reference to the Horeb gospel the tradition of which is reflected in the entire headpiece. In its only figurative illustration heading the Eothina lections and depicting Christ above and three evangelists below hidden in the headpiece in yellow, red and pale blue colours, we recognize once again the portrait of Christ in the Horeb lectionary (Figs. 18, 8).

If we return once more to cod. 207 and examine the headpieces on fols. Ir and $117 \mathrm{r}$ we become aware of another distinct element in the ornament (Figs. $13,14)$. The star-like and four-petalled rosettes which do not recall the usual rosettes found in Byzantine manuscripts, as well as the birds in the medallions appear in partly painted and partly carved wooden panels in ceilings or window frames in chapels at Sinai (Fig. 19) ${ }^{35}$. These panels include also stylized birds, horses, donkeys and ducks. Unfortunately they are not dated and one can argue that they have been influenced by the ornament in the manuscripts. It is, however, more likely that the decorators of the manuscripts have attempted to imitate the panels. There are other manuscripts at Sinai with this motif and furthermore -and this is most important- these panels represent a long tradition in Islamic art. Their origin should be sought in the lustre tiles built into the mihrāb of great mosques such as at Qayrawan, c. 862 (Fig. 20) ${ }^{36}$. The influence of these Sinai panels is to be discerned again on some Arabic, unpublished icons which are in the monastery today ${ }^{37}$. In fact the presence of

34. Unpublished; Gardthausen, op. cit., p. 50; V. Lazarev, Istoria vizantiiskoi zhivopisi, Moscow 1947,1948 , p. 370 , n. 78 , proposes a thirteenth or fourteenth century date which in my opinion is not tenable.

35. J. Caley, Sinai and the Monastery of St. Catherine, Givatayin, Israel 1980, figs. 142-147; see also ceiling of the Chapel of St. Marina in G. H. Forsyth, K. Weitzmann, The Monastery of St. Catherine at Mount Sinai, Plates, Ann Arbor, n.d., pl. XCII, A, figs. B, N.

36. Talbot Rice, op. cit., p. 42, fig. 35; K. A. C. Creswell, Problems in Islamic Architecture, Art Bulletin 35 (1953), pp. 1-7, esp. p. 3, fig. 2.

37. In one of these icons representing St. Gerasimos and the Lion, the style of the animal betrays clearly the influence of the panels. 


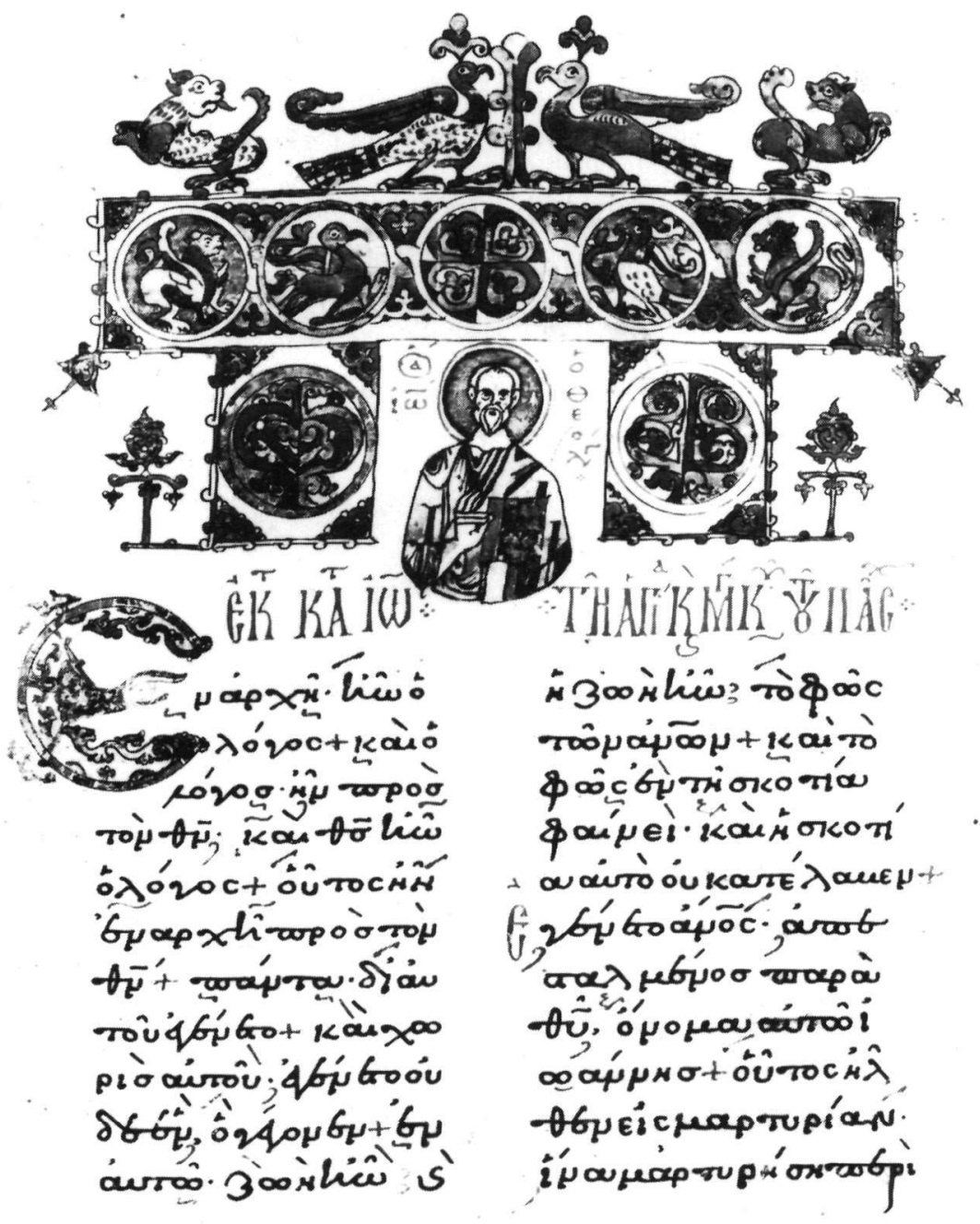

Fig. 13. Lectionary. Cod. 207. Fol. 1r.

motifs relating to the panels persisted in Sinai for long time; extant examples show that it was applied in various ways. When, for instance, a new textual part was added to the ninth-century cod. 30 and the codex was rebound probably in the fifteenth century, "rosettes" were painted on the book-cut (Fig. 21).

At the end of the thirteenth century which marks the direct entry of the Popes into the history of Sinai (we have a series of Popes beginning with 


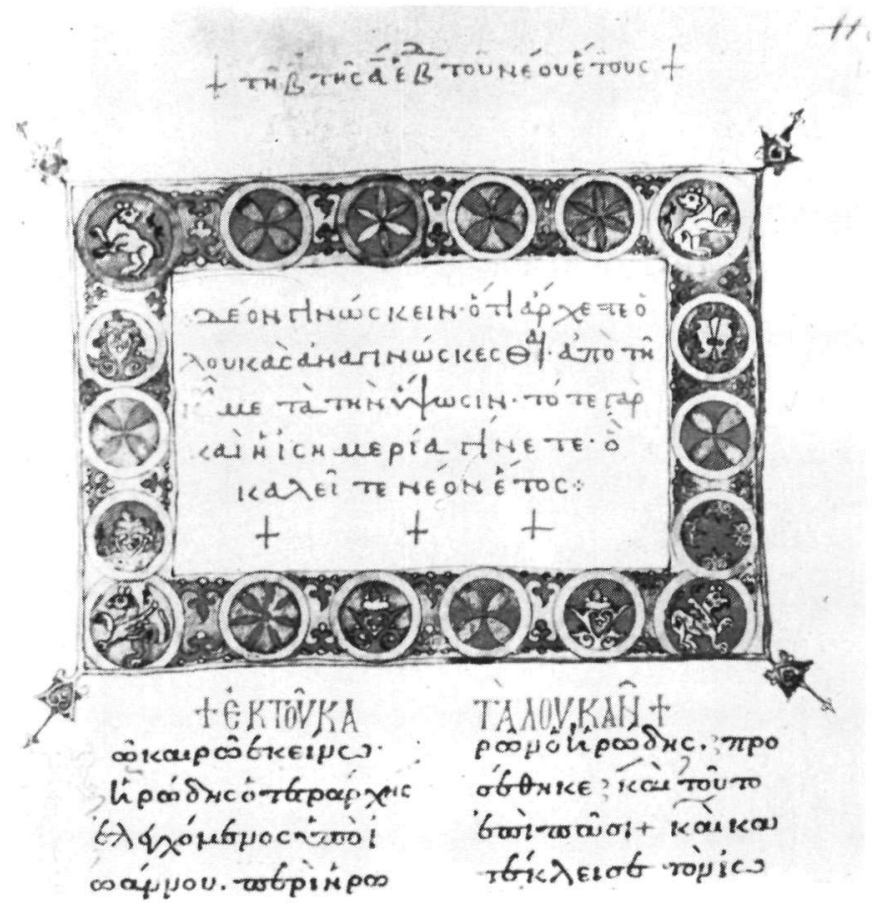

Fig. 14. Lectionary. Cod. 207. Fol. 117r.

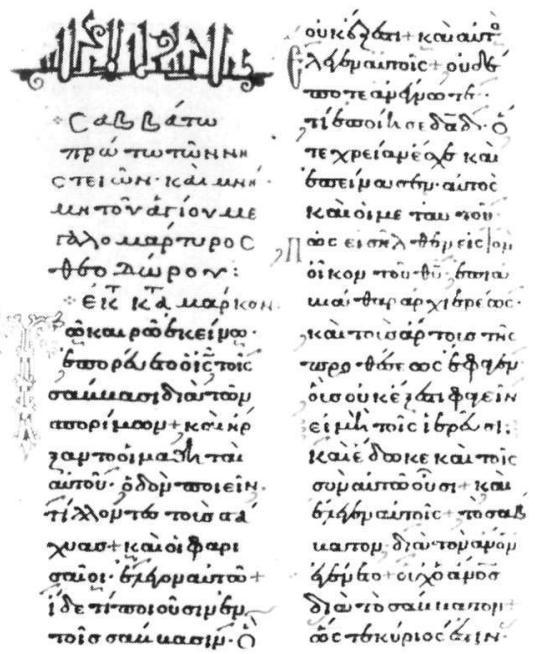

Fig. 15. Lectionary. Cod. 207. Fol. 210r. 


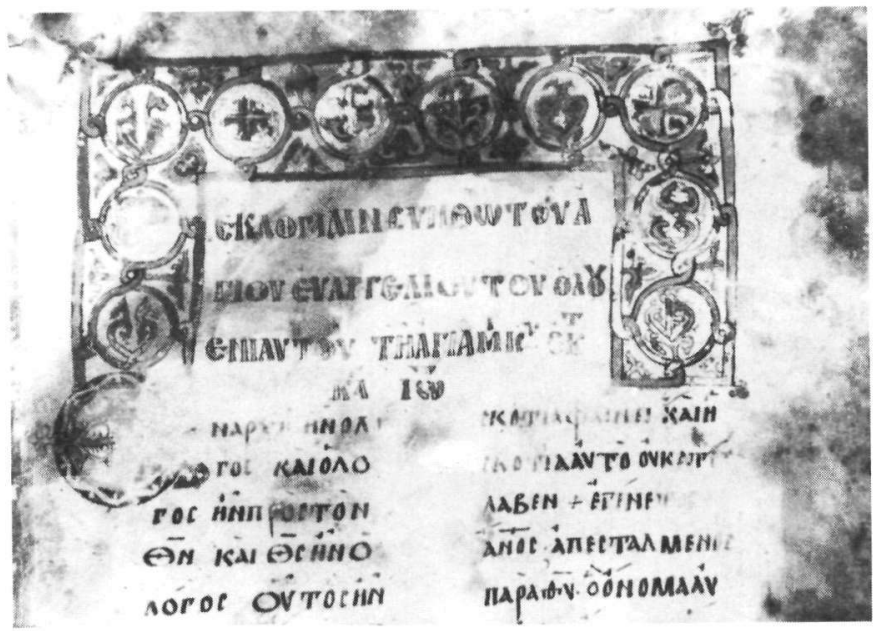

Fig. 16. Lectionary. Cod. 214. Fol. 1r.

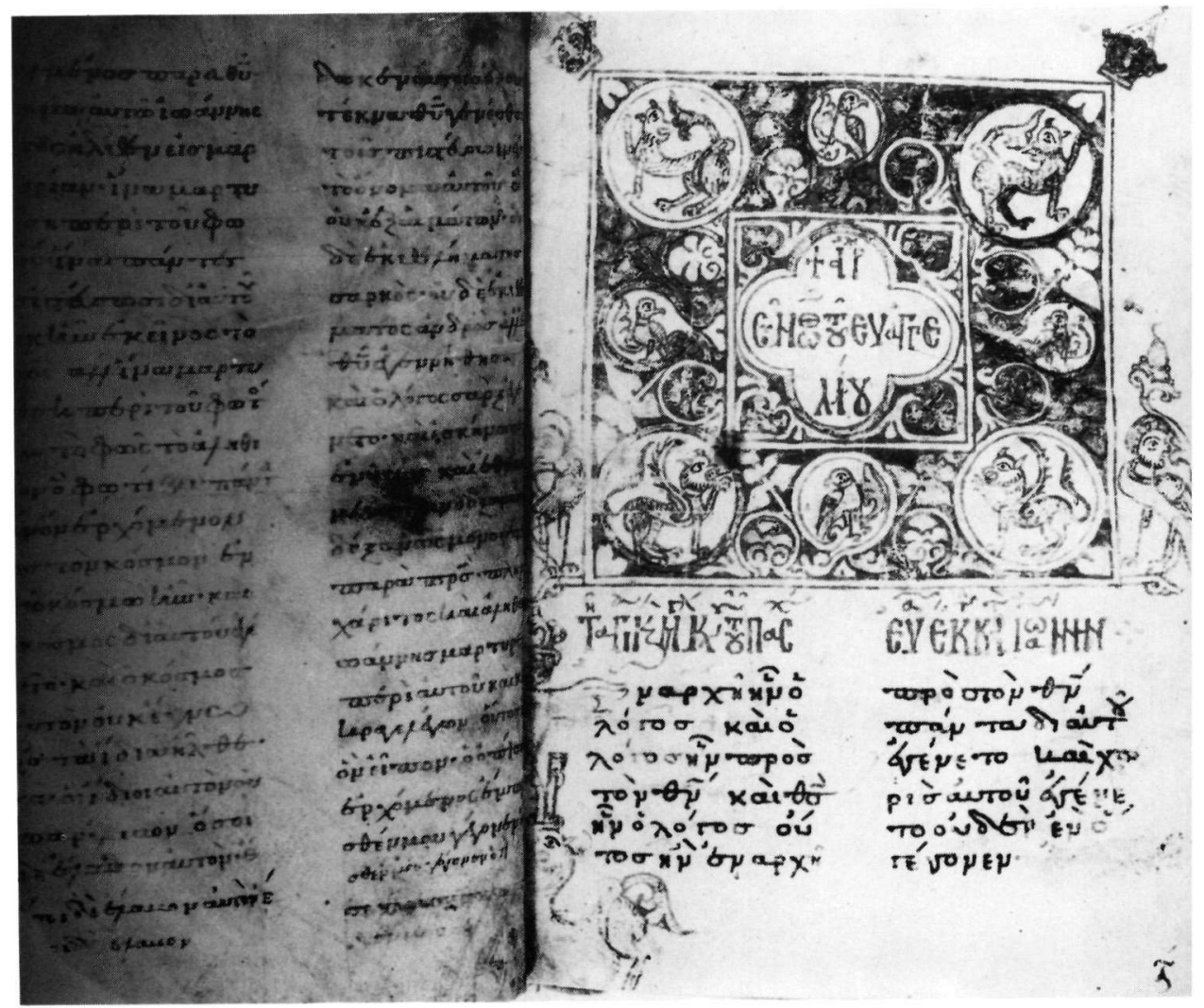

Fig. 17. Lectionary. Cod. 237. Fol. 2r. 


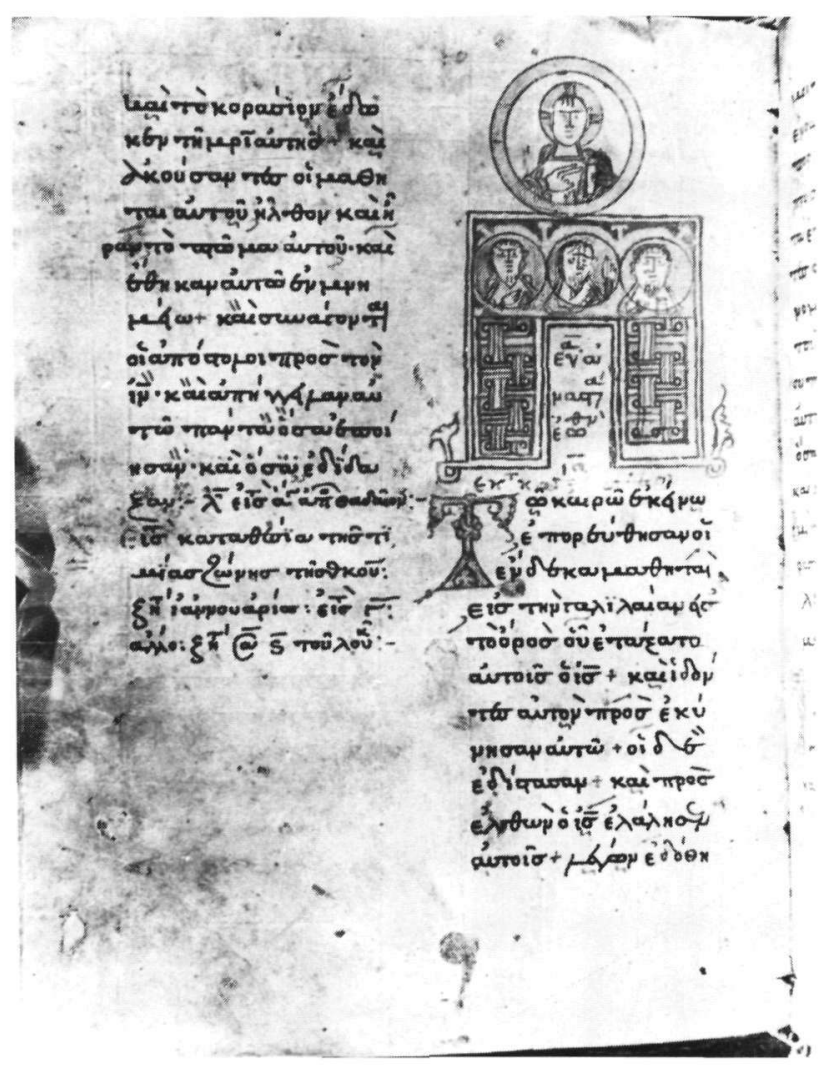

Fig. 18. Lectionary. Cod. 237. Fol. 117v.

Fig. 19. Painted ceiling panels, Sinai.

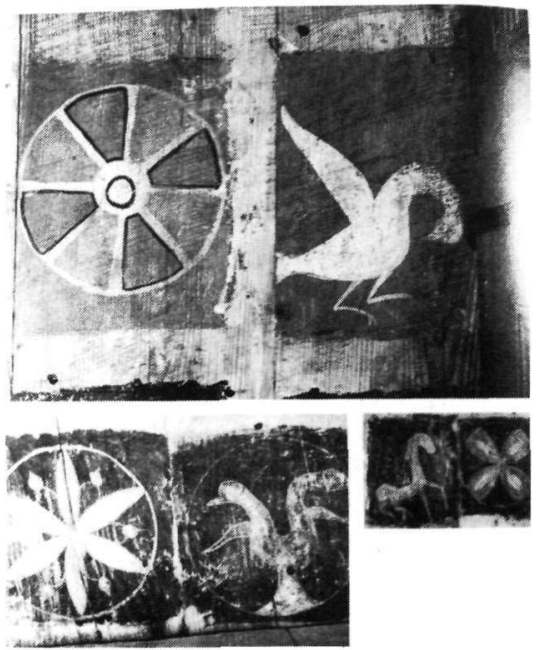


Honorius III who extended their protection to the monastery $)^{38}$ we have another group of manuscripts written in various languages, all of them liturgical books: psalters, kondakaria, sticheraria, akolouthiai ${ }^{39}$. Motifs and style of ornament and other features are identical in all of them. Seven written in Greek are dated and localized by colophons in Sinai between 1285 and $1299^{40}$. Thus there can be no doubt that the entire group was produced in Sinai. In fact it seems that attempts towards the creation of this particular style had been made earlier in the century for there is another lectionary cod. 201, dated to the year 1244 which has comparable stylistic characteristics in patterns and colour scheme, i.e. terracotta red, yellow and deep green (Fig. 22) ${ }^{41}$.

All these manuscripts are written on paper and the Greek ones have titles in Arabic and in some instances entire pages written in Arabic by the same scribe who wrote the Greek text. Their ornamentation is exemplified here by the two headpieces that of a sticherarion, cod. 1224, fol. Ir, one of the most elaborate examples and that of a lectionary, cod. 251, fol. lr (Figs. 23, 24) ${ }^{42}$. The same motifs and style are also found in a Syriac manuscript, cod. Syr. 127, with akolouthiai, an Arabic lectionary, cod. Arab. 680, from the year 1333 and a leaf from another Arabic lectionary ${ }^{43}$. To these one should also add fragments of manuscripts with similar ornament found among the new Sinai-discoveries which indicate further the extent of this Sinaitic production. The identical motifs are: different types of rosettes, some of them taking the form of an interlaced cross, crenellations common in Byzantine manuscripts and elaborate frames with a rinceau shooting into the margins, all rendered in a carpet like style in flat, pale water colours, light carmine, yellow and deep green.

In the rosettes, we can see without any doubt the painted wooden panels of the Sinai chapels. The interlaced cross in itself is common in Byzantine manuscripts and a search for its origin is not necessary. Nevertheless, at first these crosses remind us of the ornament found in the early antecedents of the present manuscripts, the bilingual Greco-Arabic psalters of the eighth and

38. Amantos, 'Ioro@í $\alpha$, pp. $36 \mathrm{ff}$.

39. Weitzmann, Sinai Mss, pp. 26-27.

40. Cited in chronological sequence, these codices are: 927 (1285), 131, 132, 662, 670 (all four from the year 1292), 94 (1294), 657 (1299). Of these dated manuscripts only a headpiece of the Kondakarion cod. 927 has been published, see Spatharakis, Dated Mss, no. 193, fig. 355 with the earlier bibliography. For the other codices see Gardthausen, op. cit., pp. 20, 26, 150, 153, 197; Benešević, op. cit., pp. 171, 172, 624, 625, 628.

41. Gardthausen, op. cit., p. 40; Benešević, op. cit., 1, pp. 95-96, 625 no. 76; id., Monumenta Sinaitica archaeologica et palaeographica, Fasc. 1-2, St. Petersburg 1912, 1, pl. 61.

42. Weitzmann, Sinai Mss, fig. 37. Cod. 251 is unpublished, see Gardthausen, op. cit., p. 512.

43. Weitzmann, Sinai Mss, pp. 26-27, figs. 38-40 with earlier bibliography. 


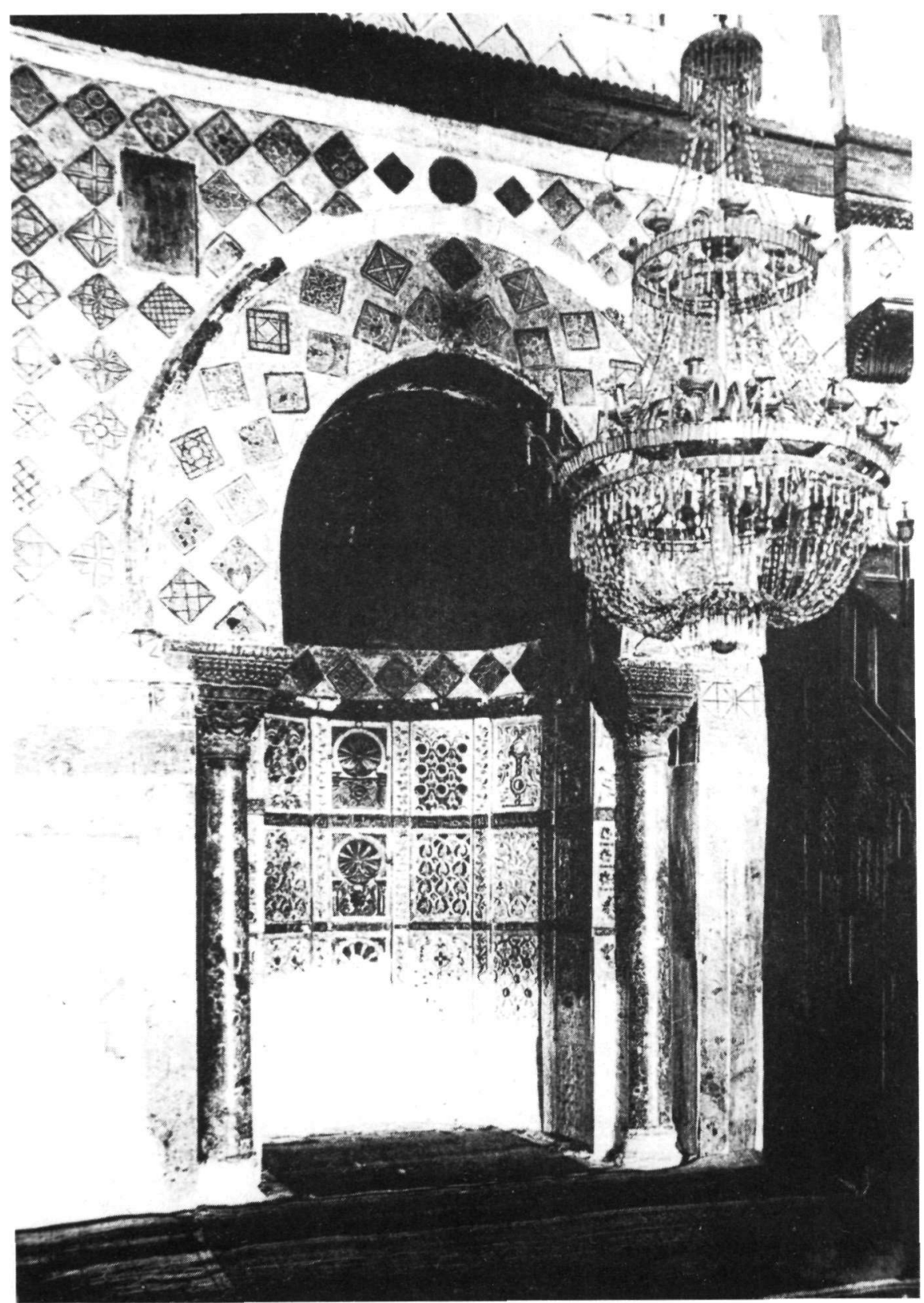

Fig. 20. Mihrāb, Great Mosque, Qayrawan. 

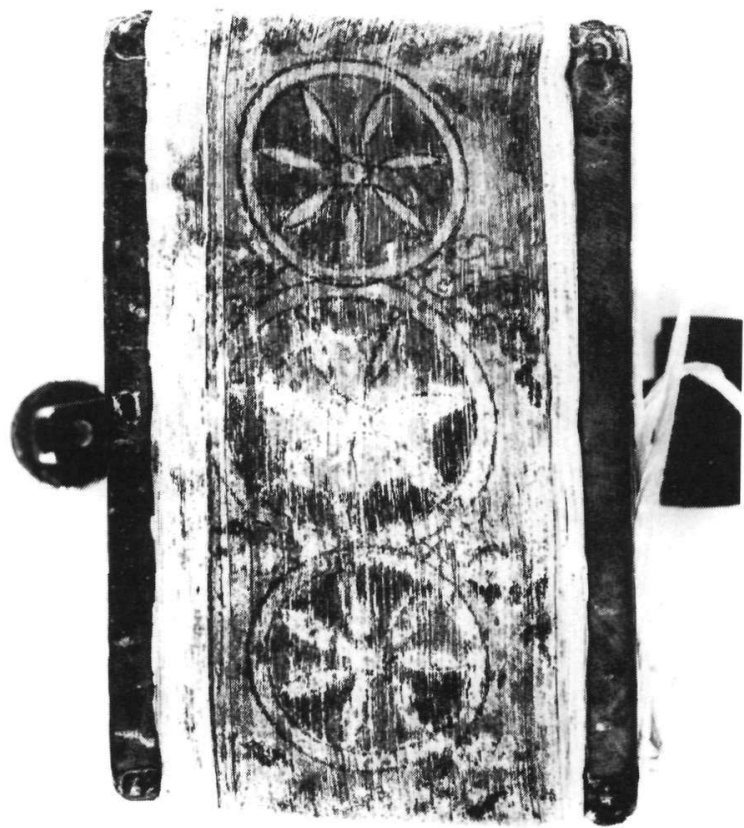

Fig. 21. Psalter. Cod. 30. Book-cut.

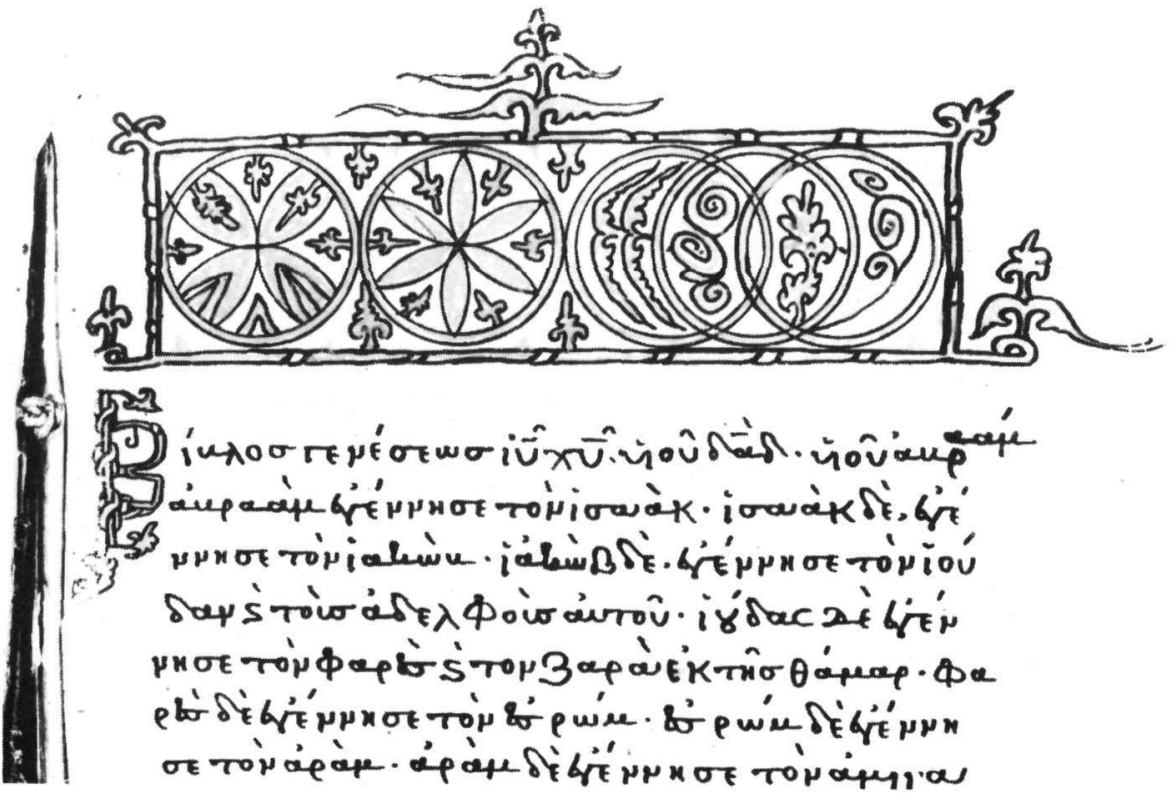

Fig. 22. Gospels. Cod. 201. Fol. 3r. 


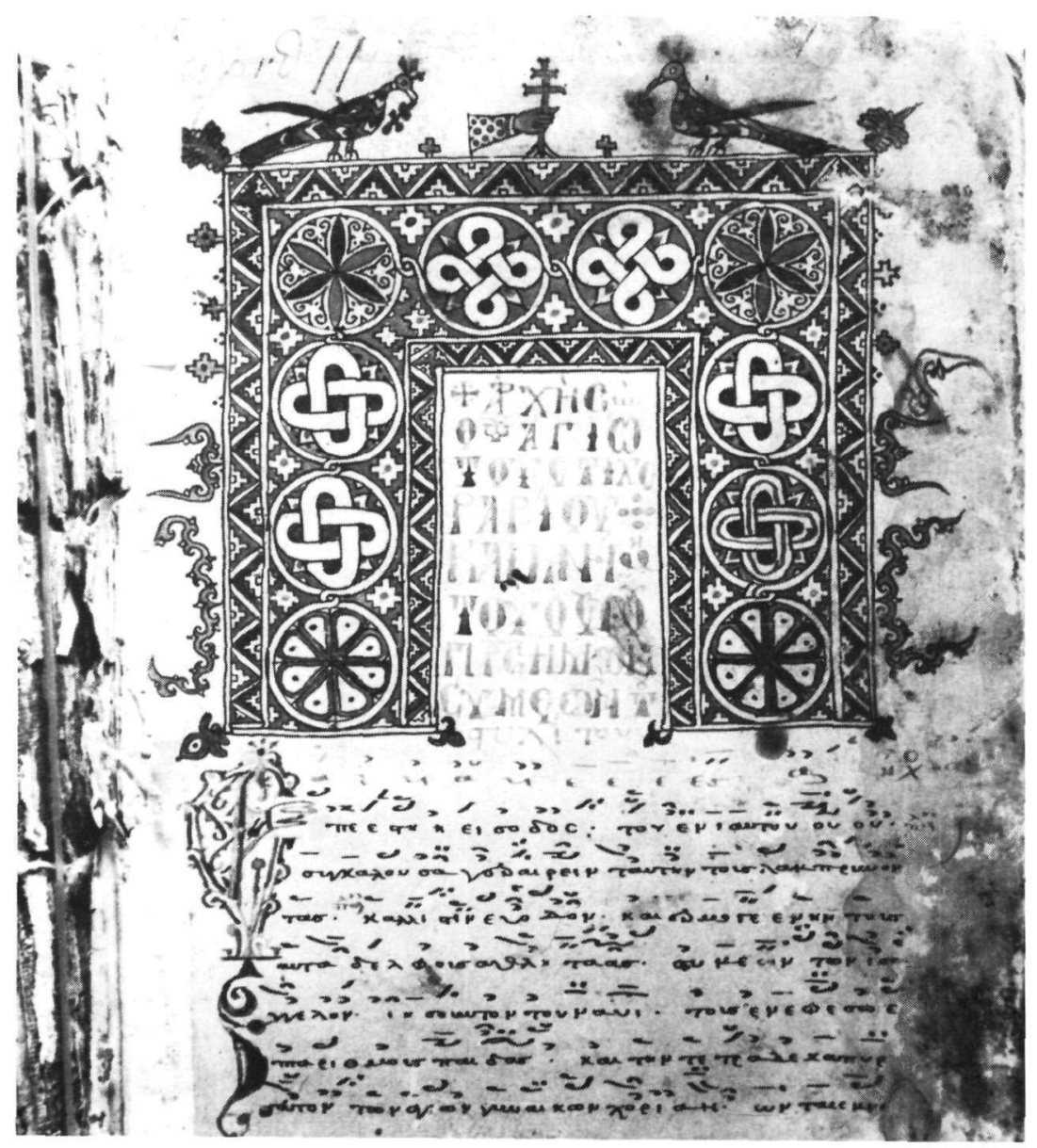

Fig. 23. Sticherarion. Cod. 1224. Fol. 1r.

ninth century. Although the survival of this feature in Sinai itself through the years cannot be excluded, a careful examination of the rendering of the crosses set in the vertical bars of the headpiece under discussion raises the possibility of the renewal of this old motif through another more immediate source: the wooden panels of the door leading from the Chapel of the Forty Martyrs to the south aisle of the Justinianic basilica with which the monks were more than familiar (Fig. 25) ${ }^{44}$. Furthermore the fretsaw rinceau and stylized palmettes shooting into the margin and the crosslets deserve our attention for they are 
most uncommon in Byzantine manuscripts. We are not referring to floral motifs appearing on Canon tables, elaborate palmettes-akroteria and the like found on top of headpieces. Here one is confronted with a mentality that denies the proper aesthetic function of the frame which is to inscribe and to limit the enclosed. On the contrary, the frame has been changed into an ornament spreading out into the margins. The headpiece ceases to recall the classical, straight metope. Whenever this element is found in provincial Byzantine codices, it betrays non-Greek and especially Coptic influences ${ }^{45}$. In fact this mentality constitutes a feature of Coptic and Arabic manuscripts and it has a long history ${ }^{46}$. It was later to become an important feature of post-Byzantine book illumination ${ }^{47}$.

Indeed Islamic influences on Sinaitic productions must have continued through illuminated manuscripts in the thirteenth century as well, as it is shown by a miniature depicting Moses Receiving the Law which was painted in a psalter, cod. 44, from the year 1122, at about this time (Fig. 26) ${ }^{48}$. Moses' oriental looking green mantle, the facial type, the mongolian eyes and the turban remind us of the several copies of the "Assemblies" (Maqamat) of Al-Hariri of the thirteenth century which have survived to this day but not their high artistic quality ${ }^{49}$.

While this group of manuscripts was produced c. 1300 there were other liturgical codices made in Sinai, according to their colophon, which we shall not touch upon here. We can only say that their decoration reveals an artistic exhaustion.

\section{III}

If my preliminary sketch is plausible -and it should be stressed that I have

45. Cf. cod. Athens, Nat. Lib. 74, Chatzinicolaou - Paschou, op. cit., no. 9, figs. 76-79.

46. The examples are several, see M. Cramer, Koptische Buchmalerei, Recklinghausen 1964, fig. 69, pls. XII and XIII and passim. With regards to this "frame-mentality" one should also consider the illustrated "references" to a paragraphos in Coptic manuscripts, see ibid., pp. $18 \mathrm{ff}$., figs. $11,12,15$.

47. For examples see, among other recent works, the study of O. Gratziou, Die dekorierten Handschriften des Schreibers Matthaios von Myra (1596-1624), Athens 1982.

48. Spatharakis, Dated Mss, no. 133, fig. 248 and A. Cutler, The Aristocratic Psalters in Byzantium (Bibliothèque Cahiers Archéologiques 13), Paris 1984, no. 47, fig. 299. These scholars make no reference to the chronological discrepancy between the miniature and the text of the psalter.

49. See Paris, Bibl. Nat. MS Arabe 3929 and MS Arabe 6094, reproduced in Talbot Rice, op. cit., figs. 105, 106. See also O. Grabar, The Illustrations of the Maqamat, Chicago 1984, only for library use with illustrations on microfilm. 


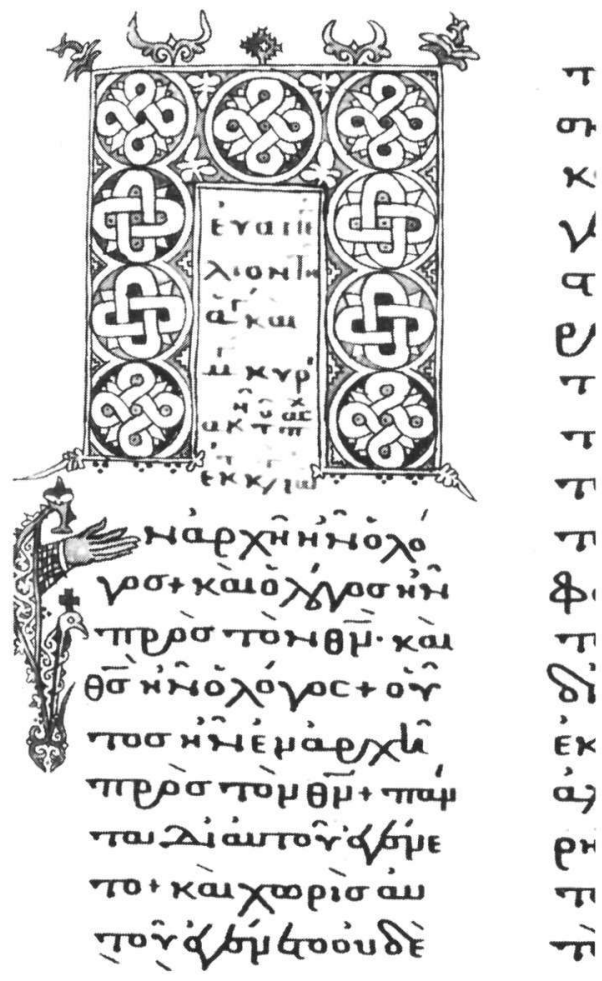

Fig. 24. Lectionary. Cod. 251. Fol. 1r.
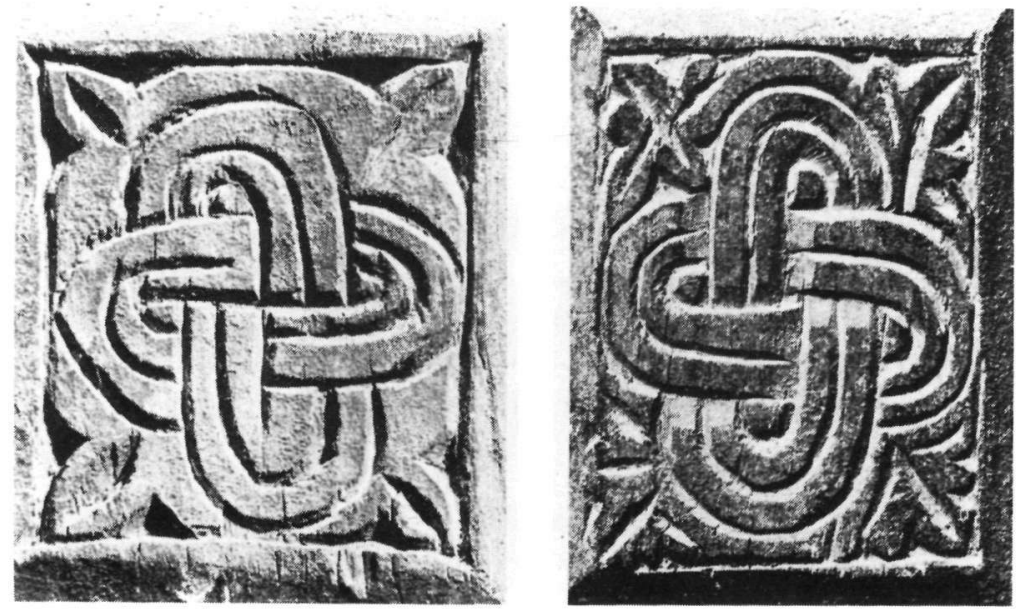

Fig. 25. Wooden doors, Chapel of the Forty Martyrs, Sinai. 
not tried to solve or even to outline all problems related to manuscriptillumination at Sinai- it is time that we see its ramifications. The earliest codices produced after the Arab conquest in the eighth and ninth century limit their decoration to simple ornament. To a large extent, the beautiful hieratic script plays a great role in substituting or supplementing the decoration. In the tenth century two manuscripts of excellent quality -the John Climacus and the Horeb lectionary-display an emphasis on the ornament and influences coming from the Islamic and Coptic worlds. The uniconic element continues and is further stressed in later productions, especially in the twelfth and thirteenth century, which never reach the quality of the earlier works. Whenever subsequent illustrators wished to create something different turned their attention to sources that existed within the walls of the monastery. Our impression is that by this time nothing new was reaching these closed surroundings and that if there were splendid Constantinopolitan manuscripts in the library, it seems, they never had an impact on local productions. It is true that the uniconic element reflects the Islamic territory in which the monastery has existed; the uniconic tradition of the Islamic world. But it may well express something more than that. Perhaps one can say that these codices reflect to a large extent the vissicitudes of the monastery. In themselves they may represent concessions to Islam which have taken various forms in the history of Sinai -the building of the mosque is a well known case in point ${ }^{50}$. Despite all the protection extended to Sinai by the Arabs and the West, the monks lived in a precarious state of existence and in constant struggle, as we are reminded by few highlights in the long history of the monastery.

The Fatimid Chalif Abu Ali Melek Dahar known as Al-Hakim (996-1021) threatened to destroy Sinai which was saved after the monks gave to the assailant all their gold and silver vessels. In 1091 the archbishop of Sinai John the Athenian was murdered by the Egyptians who attacked the monastery. Even when relations with the Arabs were friendly, as for example the reported visits of the Chalif of Bagdad show, the monks were always very careful not to provoke the Arabs. When Baldwin II, king of Jerusalem, wished to visit Sinai as a pilgrim in 1116, the monks asked him to abandon his intentions least the Arabs attack the monastery after his departure ${ }^{51}$.

Our manuscripts seem to reflect all these events. The monks produced what was absolutely necessary to fill their liturgical needs and in a way that should

50. Amantos, 'Ioto@í $\alpha$, pp. 23 ff. with earlier bibliography

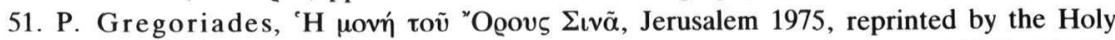
Monastery of Sinai, Athens 1978, pp. 78-81; Papamichalopoulos, op. cit., pp. 235 ff., 241 ff., 338 ff.; Amantos, 'Ioto@ía, p. 43. 
not be offensive to the Arabs. But were they indeed cut off from Constantinople and did not the Constantinopolitan products which we assume were in the library make any contributions to the artists? Certainly they could have contributed a great deal at least in the realm of ornament and technique.

An examination of the codices has shown that all of them bear signs of heavy handling. On the contrary the de luxe Constantinopolitan manuscripts, now in the library, do not indicate a heavy use. I have also come across notices according to which certain manu-

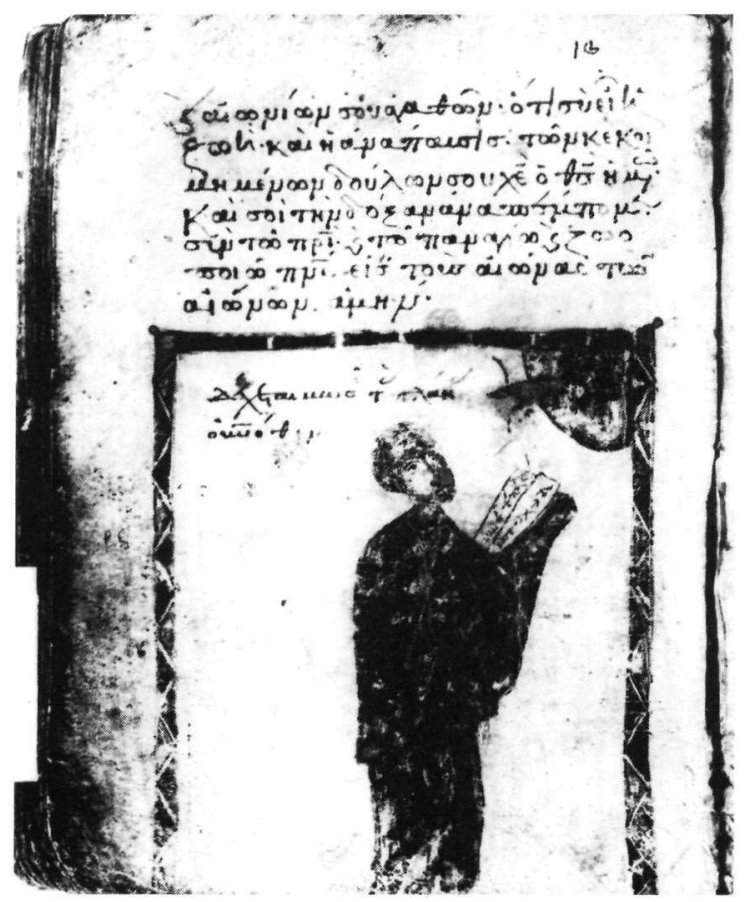

Fig. 26. Moses Receiving the Law. Psalter. Cod. 44. Fol. 95v.

scripts were not to be removed from a particular place. Were these Constantinopolitan manuscripts kept as keimelia ${ }^{52}$ or simply hidden from the eye of an ordinary, dangerous visitor? I cannot answer these questions at present. I can, however, point out that in monastic communities it is customary to keep precious lectionaries in the skevophylakion. They are to be used on Easter Sunday for the reading of the pericope of the day in the Liturgy and for presenting to the congregation a book which overwhelms one with its grandeur suitable to the character of the feast. Furthermore, for a number of these Constantinopolitan codices proof can be provided that they reached Sinai after the fall of Constantinople.

This conclusion raises some fundamental questions. How shall we explain

52. The question of manuscripts as keimelia has been raised in a different context by St. Papadaki-Ökland, The Illustrations of Byzantine Job Manuscripts, Ph. D. Dissertation, unpublished, Heidelberg 1979, p. 203 f. 
the presence of so many Constantinopolitan icons in the monastery? And how do the manuscripts relate to icons surely produced in the monastery? And what are the connections of the codices to the "orientalizing" and bilingual, Greek and Arabic icons which are now at Sinai? Do the icons parallel the case of the manuscripts? These questions must be left unanswered at present. The answer may be given when the publication of all icons Byzantine, PostByzantine, "Orientalizing" and non-Byzantine by K. Weitzmann and M. Chatzidakis is completed.

When and how Constantinopolitan codices came to Sinai and what their wanderings can tell us about manuscript painting after the fall of Constantinople and above all about the piety of the Greeks - this constitutes another story which I hope to relate on another occasion.

My thanks go to: the Christian Archaeological Society for inviting me to participate in the celebrations of its hundredth anniversary which prompted the writing of this paper; His Beatitude Archbishop Damianos and the Fathers of the Monastery -Father Demetrios, the Librarian, in particular- for supporting and facilitating my researches at Sinai in every way; Professor Kurt Weitzmann for sharing his vast knowledge as always; Dr. Manolis Chatzidakis, Academician, for profitable, stimulating discussions and much kindness. After the delivery of my lecture in Athens, I was supplied very generously with information pertaining to the new manuscript-finds at Sinai. Dr. Panayotis Nicolopoulos put at my disposal the proof of his forthcoming book on the new Greek manuscripts and Dr. Ioannis Meimaris discussed with me the photographic material of the new Arabic manuscripts the publication of which he is preparing. I owe them special thanks. Subsequently, I examined and supplemented all this personally in Sinai. The evidence of the new finds corroborates that presented in this paper.

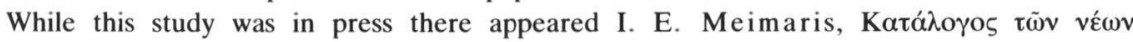

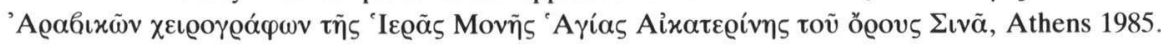

Photo credits 1, 2, 4, 5, 8-10, 12, 13, 15-17, 21, 22, 24, 26, courtesy of the Monastery of St. Catherine's, Mt Sinai; 3, 6, 7, 11, 14, 18, 23, courtesy of the Michigan-Princeton-Alexandria Expedition to Mount Sinai; 20, after Galey; 21, after Creswell; 24, after Forsyth, Weitzmann.

All photos are presented in the sequence of the folios in each manuscript. 